\title{
Synthesis of Fatty Acid Methyl Ester from Soybean Oil Using Electrolysis Enhanced by Treated Kaolinite as Catalyst
}

\author{
Rudy Syah Putra ${ }^{1,2 *}$, Wahyu Sriyono ${ }^{1}$, Mutiara Ayu ${ }^{1}$, and Reina Intan Kusumawati ${ }^{1}$ \\ ${ }^{1}$ Department of Chemistry and New and Renewable Energy Research Group, Universitas Islam Indonesia, Jl. Kaliurang km. 14, \\ Yogyakarta 55584, Indonesia
}

\begin{abstract}
The performance of treated kaolinite obtained from three types treatment that was calcination at $600{ }^{\circ} \mathrm{C}(\mathrm{K} 600), 800{ }^{\circ} \mathrm{C}(\mathrm{K} 800)$ and acid treated of K800 (KA800). All catalysts were tested for their catalytic activity via electrolysis process through (trans)esterification of soy bean oil at room temperature. X-ray diffraction (XRD) and Fourier transform infrared (FTIR) was performed to characterize the microstructures and chemical properties of as-prepared treated kaolinite material. The effect of catalyst amount $(2,3$ and 5 wt.\%) was evaluated for the conversion of FAME from soybean oil and followed by GC-MS, determining of the purity of FAME at different operation variables. The result showed that for KA800 as catalyst, the FAME conversion was the highest as well as $18,85 \%$ at 3 wt.\% catalyst of catalyst loading in the mixture, respectively.
\end{abstract}

\section{Introduction}

The depletion of fossil fuel production be accompanied with climate change in the world has encourage world researchers to find renewable energy sources namely biodiesel as an alternative energy source developed to substitute the fossil fuels. Based on data between 2005 and 2015 presented by Naylor and Higgins (2017) showed that the global biodiesel production continues to increase by $\sim 23 \%$ per year despite a sharp decline in crude oil prices. This coincides with a sharp rise in the price of crude oil and diesel fuel that makes some countries support the use of biodiesel [1].

Biodiesel synthesis processes typically use renewable sources such as vegetable oils, animal fats and recycled cooking oil [2] are carried out by (trans)esterification of triacylglyceride with methanol and assisted with homogeneous alkaline catalysts, such as $\mathrm{NaOH}$ and $\mathrm{KOH}$ which produce Methyl Ester Fatty Acid (FAME) as a product main and glycerol as by-products [3]. Homogeneous alkaline catalysts are extremely sensitive to Free Fatty Acid (FFA) contained in low quality cooking oils that lead to saponification, decreased catalyst quality, decreased synthesis efficiency and increased production costs. Guan and Kusakabe [4] reported that the synthesis of biodiesel from used-cooking oil using electrolysis process have a yield percentage of $>97 \%$. This process runs quickly at relatively low temperatures, but this method is less efficient because once the process is complete, it has to separate between the biodiesel and the homogeneous catalyst that used. In addition, the homogeneous catalyst could not be regenerated after (trans)esterification process. Furthermore, a large amount of Indonesian society on the consumption of palm oil as a vegetable oils thus increasing the availability of usedcooking oil as feed-stock in the producing of biodiesel. The conversion of used-cooking oil into biodiesel is a smart move, which gives three advantages at once namely (i) its economic value, (ii) becomes a solution for handling used-cooking oil and (iii) producing an environmentally friendly biodiesel products [3].

Jorge et al. (2011) [5] has reported the production of biodiesel from used-cooking oil by transesterification reaction using methanol and kaolinite as a solid acid catalyst. This study has become a positive alternative to utilizing used-cooking oil as feed-stock combined with a cheap kaolinite catalyst. Kaolinite is a raw material that has a selling value, cheap, available, non-corrosive and environmentally friendly materials. In this study, the enhancement of FAME synthesis from soybean oil using electrolysis process by treated kaolinite thermal and acid as catalyst in room temperature was demonstrated.

\section{Methodology}

\subsection{Chemical and equipment}

Soybean oil was obtained from supermarket. High grade of methanol, $\mathrm{HCl}, \mathrm{NaCl}$ and co-solvent THF were purchased from Merck, Germany and the kaolinite was purchased from Wako Chemical, Japan. Fig. 1 shows an electro-catalytic cell $(70 \mathrm{ml})$ contains two graphite electrodes $(\varnothing 0.8 \mathrm{~mm} \times 130 \mathrm{~mm})$ that were separated by a distance of $15 \mathrm{~mm}$ [3-4]. The qualities of soybean oil were determined by physicochemical analysis and the results were shown in the Tab. 1.

\footnotetext{
Corresponding author: rudy.syahputra@uii..ac.id
} 
Table 1. Physicochemical properties of soybean oil

\begin{tabular}{ccccc}
\hline Oil & $\begin{array}{c}\text { Acid } \\
\text { Number }\end{array}$ & $\begin{array}{c}\text { Refractive } \\
\text { index }\end{array}$ & $\begin{array}{c}\rho, \\
\mathrm{Kg} / \mathrm{L}\end{array}$ & $\begin{array}{c}\text { Moisture, } \\
\%\end{array}$ \\
\hline Soybean & 0.138 & 1.469 & 0.920 & 0.217 \\
\hline
\end{tabular}
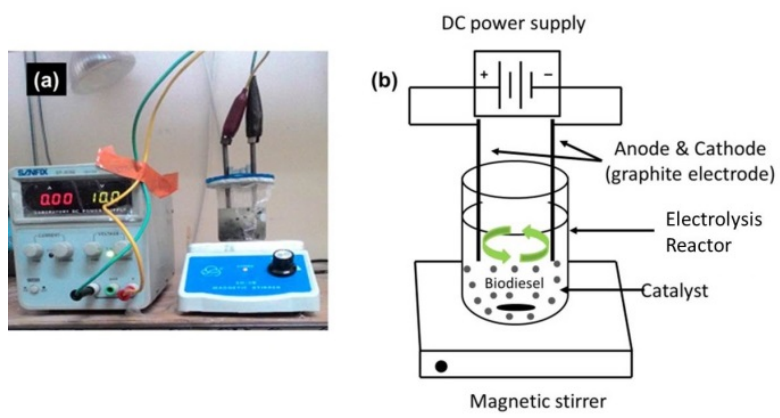

Fig. 1 Electrolysis reactor set up (a) and illustrated functional apparatus in the reactor (b).

\subsection{Preparation and characterization of catalyst}

Treatted kaolinite was prepared by calcination of a natural kaolinite at $600{ }^{\circ} \mathrm{C}$ and $800{ }^{\circ} \mathrm{C}$. This kaolinite, more reactive than the parent kaolinite, was submitted to acid activations. Acid activation was carried out with $6 \mathrm{M} \mathrm{HCl}$ at room temperature with times of treatment of $24 \mathrm{~h}$ [6]. X-ray diffraction (XRD), Fourier transform infrared (FTIR) was performed to characterize the microstructures and chemical properties of as-prepared acid-calcination of kaolinite material. The performance of FAME synthesis using electrolysis was compared between acid activation and treated kaolinite thermal. The FAME phase was separated from glycerol and then washed with deionized water to remove the residual inorganic components. Concentration of produced FAME and unreacted oils remaining in the product were measured using GC-MS.

\subsection{Catalytic testing}

Soybean oil was used as a feedstock to obtain optimal condition before implemented to used-cooking oil for FAME synthesis. Effect of catalyst amount (2, 3 and 5 wt.\%) were evaluated for the conversion of FAME from soybean oil. The reaction mixture was agitated using magnetic stirrer. The electrolytic cell was filled with 70 $\mathrm{ml}$ of reaction mixture containing soybean oil, methanol, THF as a co-solvent. The methanol-to-oil molar ratio was 6:1 and co-solvent-to-methanol molar ratio was $1: 1$ were added on the basis of oil weight of the entire reaction mixture, respectively. The electro-catalytic was carried out at room temperature $\left(25^{\circ} \mathrm{C}\right)$ using a constant voltage of $18.2 \mathrm{~V}$ for $60 \mathrm{mins}$ [3-4]. Fig. 2 shows a step of optimization process for biodiesel production in this study. This method is free from hazardous and expensive reagents, contamination and the product can be separated by simple filtration.

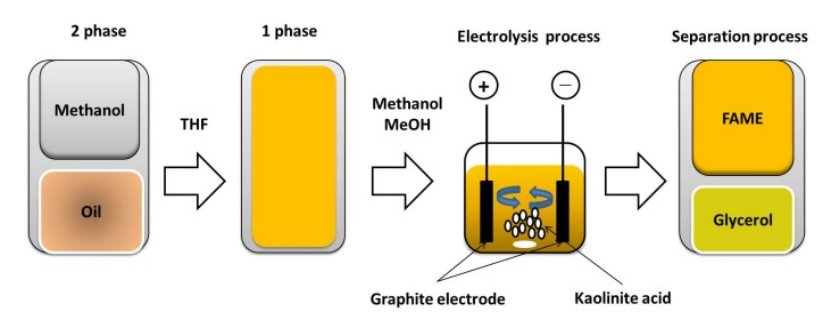

Fig. 2 Steps on FAME synthesis using electrolysis process and kaolinite acid as catalyst.

\section{Results and discussion}

\subsection{Catalyst characterization}

Generally, the structural of clay material changed after the thermal and acid treatment. Figure 3 shows the XRD profiles of the untreated and treated kaolin samples. The parent clay shows well-defined reflections at $2 \theta$ value of $12^{\circ}, 25^{\circ}$ (corresponding to the $d$ values of $7.154 \AA$ ). These peaks correspond to the reflections from [001], which are typical characteristic peaks of kaolinite [7]. After acid treatment, the peak intensity of the clay was found to decrease, since leaching was quite severe with strong acids. This was attributed to the structural disorder that occurred owing to the acid leaching, which affects the crystalline character of the clay. The increase in intensity and/or narrowing of the peak may be related to the increase of crystallite size and/or the decrease of the mean lattice strain [8].

The FTIR spectrum of the clay peaks at 3673,1119 , 1044, 946, and $798 \mathrm{~cm}^{-1}[6]$ as shown in Fig. 4. There was not much variation in the peak pattern for acid treated kaolinite. However for thermal treated kaolinite, the peak intensity was found to decrease progressively indicating the loss of structural water with a reorganization of the structure; only a small part of $\mathrm{AlO}_{6}$ octahedra is maintained, while the rest are transformed into much more reactive tetra- and pentacoordinated units [6].

\subsection{Effect of treated kaolinite on the FAME synthesis}

Table 2 shows the FAME conversion from soybean oil using treated kaolinite as catalyst in the electrolysis process. Generally, kaolinite which had been calcinated at 600 and $800{ }^{\circ} \mathrm{C}$ give better result in electrolysis process responded high FAME yield compared with acid kaolinite, and it was affected by $3 \%$ of catalyst loading. In K800 catalyst, all of the $\mathrm{OH}$ band dissapears due to dehydroxylation via by calcination, thereby producing thermally activated kaolinite. These transformation occcurs with the loss of structural water (see Fig. 4) in the kaolinite framework. The rest of the kaolinite was transformed into much more reactive tetra and pentacoordinated units [6]. Thus, a mild and efficient method has been developed for the (trans)esterification of fatty acid to their corresponding fatty acid methyl ester by using activated kaolinite clay in good yield. This method 
is free from hazardous and expensive reagents, contamination and the product can be separated by simple filtration.

It was showed that excellent conversion rates (as high as $18.85 \%$ ) were obtained in 3 wt. $\%$ of acid kaolinite (KA800) as a catalyst loading since total FAME yield was the highest (see Fig. 3). Total FAME on the K800 catalyst was as much as $6.47 \%$ in $3 \%$ catalyst loading, while on the K600 catalyst was as much as $2.2 \%$ in $5 \%$ catalyst loading. This fact shows that acid kaolinite was a high reactive catalyst in the (trans)esterification reaction. While, thermal kaolinite (i.e K600 and K800) showed low active catalyst, resulting a low FAME conversion $(1.63 \%$ for $\mathrm{K} 800$ and $0 \%$ for K600).

Figs. 5 show the FAME profiles from biodiesel using kaolinite thermal and kaolinite acid as catalyst in the electrolysis process. There is no sharp different of FAME yield when using thermal (K800) and acid kaolinite (KA800) at $800^{\circ} \mathrm{C}$ as catalyst. However, a sharp different FAME conversion showed when using thermal kaolinite at $600{ }^{\circ} \mathrm{C}$. High to low FAME conversion (\%) from usedcooking oil was as follow methyl linolein $>$ methyl dhypalmitine $>$ methyl hexadecanoate using kaolinite acid, respectively. These results were different for each catalyst used in the electrolysis process. Therefore, the amount of methyl ester produced was not affected by a certain methyl ester type.

Table 2. FAME conversion from soybean oil using treated kaolinite as catalyst

\begin{tabular}{|c|c|c|c|c|}
\hline $\begin{array}{c}\text { Treated } \\
\text { kaolinite }\end{array}$ & $\begin{array}{c}\text { Catalyst } \\
\text { loading } \\
(\%)\end{array}$ & $\begin{array}{c}\text { FAME } \\
\text { yield }(g){ }^{b}\end{array}$ & $\begin{array}{l}\text { Purity } \\
(\%)^{c}\end{array}$ & $\begin{array}{l}\text { Yield } \\
(\%)^{d}\end{array}$ \\
\hline Without & 0 & 2.12 & 42.17 & 3.58 \\
\hline \multirow{3}{*}{$\begin{array}{l}\text { Thermal } \\
\left(800^{\circ} \mathrm{C}\right) \\
\mathrm{K} 800\end{array}$} & 2 & 32.93 & 5.76 & 3.79 \\
\hline & 3 & 27.53 & 11.75 & 6.47 \\
\hline & 5 & 22.62 & 3.61 & 1.63 \\
\hline \multirow{3}{*}{$\begin{array}{l}\text { Acid } \\
\left(800^{\circ} \mathrm{C}\right) \\
\text { KA } 800\end{array}$} & 2 & 26.57 & 9.77 & 5.19 \\
\hline & 3 & 19.44 & 48.47 & 18.85 \\
\hline & 5 & 25.57 & 9.35 & 4.78 \\
\hline \multirow{3}{*}{$\begin{array}{l}\text { Thermal } \\
\left(600{ }^{\circ} \mathrm{C}\right) \\
\mathrm{K} 600\end{array}$} & 2 & - & - & - \\
\hline & 3 & 31.38 & 1.57 & 0.99 \\
\hline & 5 & 30.74 & 3.58 & 2.20 \\
\hline \multicolumn{5}{|c|}{$\begin{array}{l}\text { a } \text { The calculation was based on } 25 \mathrm{~g} \text { soybean oil as feed- } \\
\text { stock, }{ }^{\mathrm{b}} \text { FAME yield after washing and solvent evaporation, } \\
\mathrm{c} \text { percentage area }(\%) \text { from GC-MC, }{ }^{\mathrm{d}} \text { Yield }(\%)=[\text { FAME } \\
\text { yield }(\mathrm{g}) / \text { Oil mass }(\mathrm{g})]^{\times} \text {Purity }(\%) .\end{array}$} \\
\hline
\end{tabular}

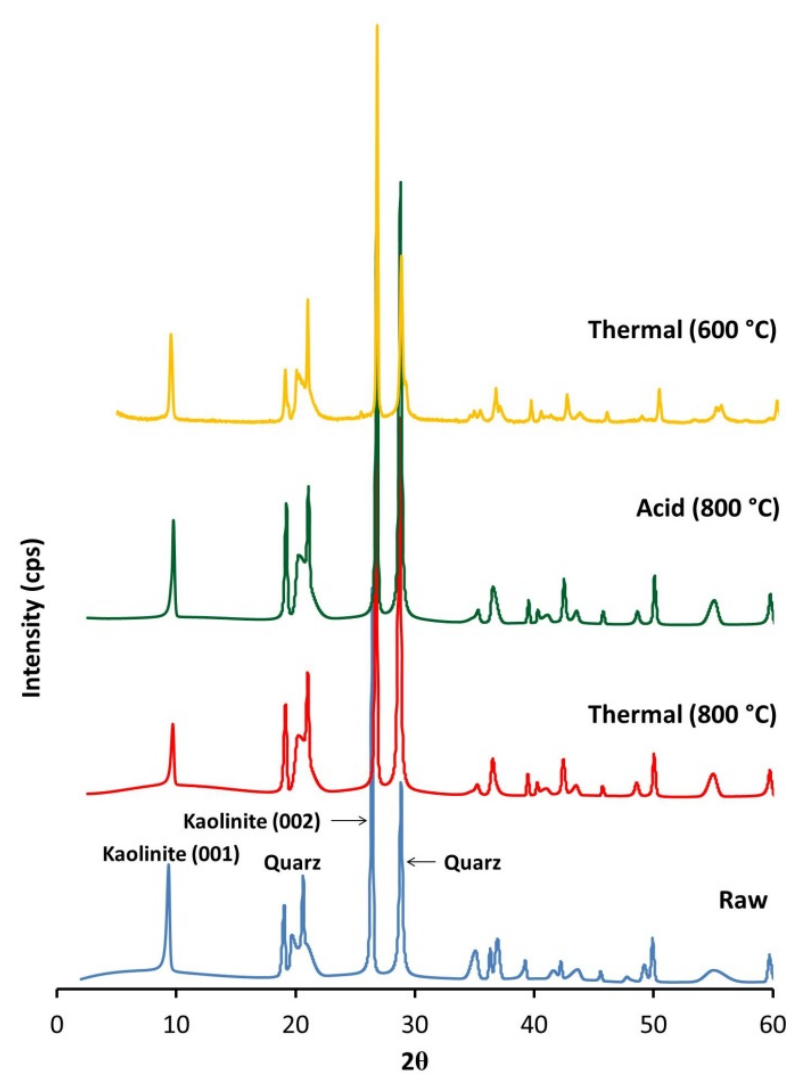

Fig. 3 XRD diffractogram of different treated kaolinite clay

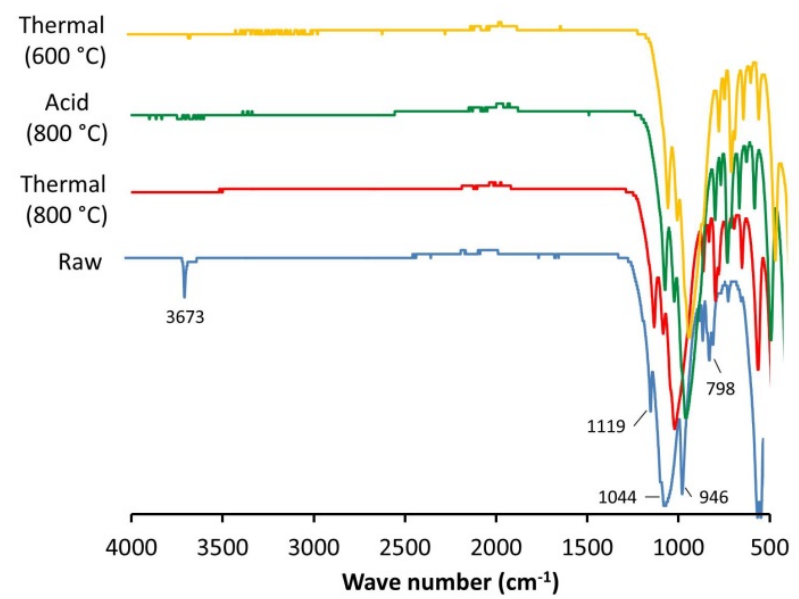

Fig. 4 FTIR spectra of different treated kaolinite clay 

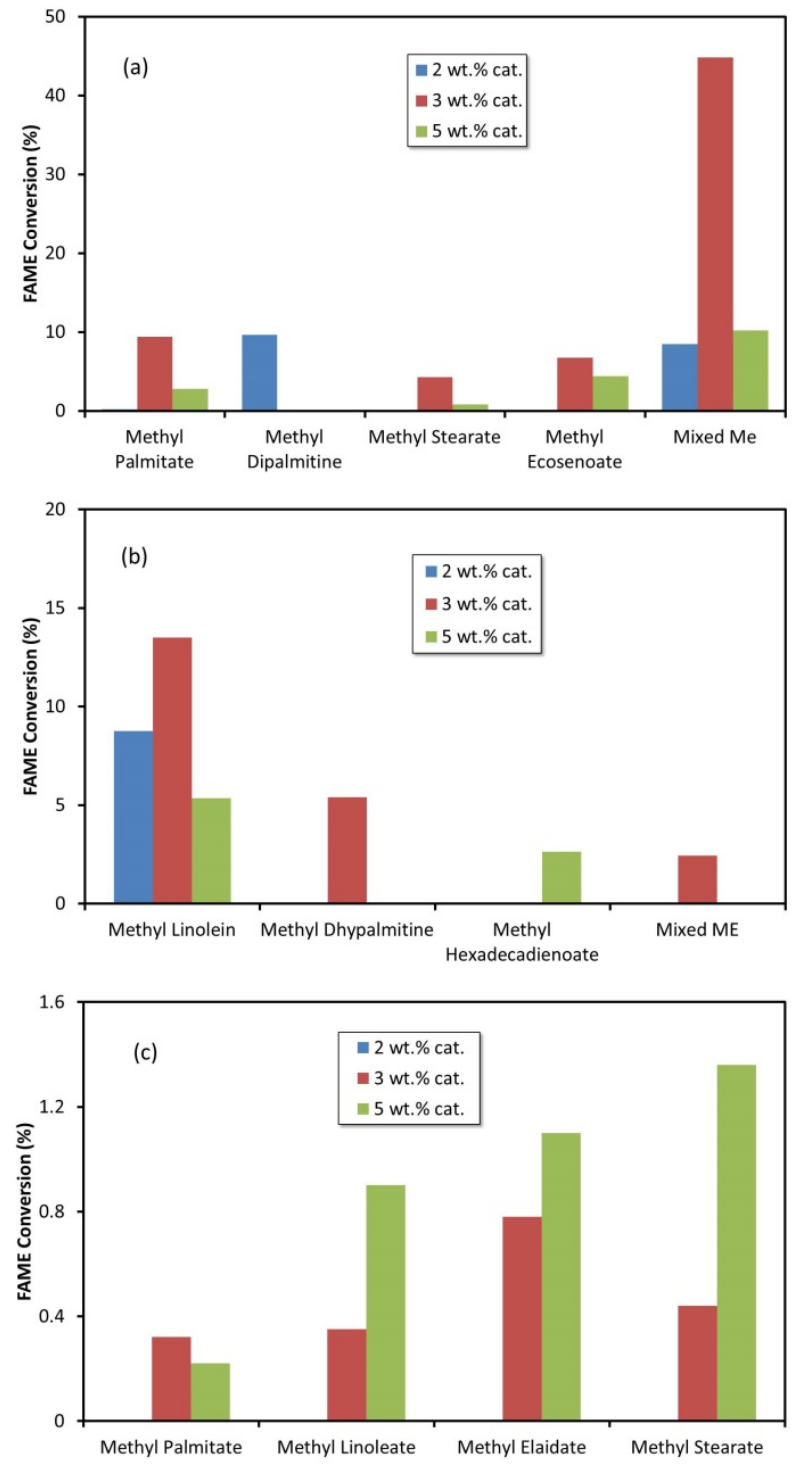

Fig. 5 FAME conversion from soybean oil in the electrolysis process using kaolinite thermal $800{ }^{\circ} \mathrm{C}(\mathrm{K} 800)$ (a), kaolinite acid $800{ }^{\circ} \mathrm{C}$ (KA800) (b) and kaolinite $600{ }^{\circ} \mathrm{C}$ (K600) as a catalyst.

\section{Conclusions}

The enhancement of FAME yield from the (trans)esterification of used-cooking oil using electrolysis process with acid kaolinite (KA800) as a catalyst had been evaluated. Acid kaolinite (KA800) as a catalyst could be a better material to enhance the electrolysis process. High catalyst concentration (3 wt. \%) of KA800 with 60 minutes of electrolysis time at room temperature was required in order to get a high FAME yield as much as $18.85 \%$ compared with thermal kaolinite K600 and K800 as a catalyst. In contrast, the results were not significantly on the FAME yield without catalyst in the electrolysis process.

Authors would like thank to KEMENRISTEKDIKTI, the Republic of Indonesia for financial support through Penelitian Produk Terapan (PPT) 2017. Furthermore, additional support from AIPT 2016 and Directorate of Talent Development and
Student Welfare of Universitas Islam Indonesia to M.A.., R.I.K. and W.S. are also gratefully acknowledged.

\section{References}

1. R.L. Naylor, M.M. Higgins, Renewable and Sustainable Energy Review, 77, 695-705 (2017)

2. G.F. Zagonel, P. Peralta-Zamora, L.P. Ramos, Talanta, 63(4), 1021-5 (2004)

3. R.S. Putra, P. Hartono, T. Julianto, Energy Procedia, 65, 309-316 (2015)

4. G. Guan, K. Kusabe, Chem. Eng, 153, 159-163 (2009)

5. J.R.Ortiz, J.M. Valtierra, M.M. Rosales, J.Eng. Tech., 56, 977-978 (2011)

6. C. Belver, M.A.B. Munoz, M.A. Vicente, Chem. Mater, 14, 2033-2043 (2002)

7. S. Kumar, A.K. Panda, R. K. Singh.Bull, Chem. React. Eng., Catal., 8 (1), 61- 69 (2013)

8. R. Delhez, T.H. Keijser, E.J. Mittemeijer, Fresenius, J. Anal. Chem, 312, 1-10 (1982) 